Original Paper

\title{
IL-1 $\alpha$ Up-Regulates IL-6 Expression in Bovine Granulosa Cells via MAPKs and NF-kB Signaling Pathways
}

\author{
Meng Yang Xurong Wang Lei Wang Xuezhi Wang Zhiqiang Yang Jianxi Li \\ Lanzhou Institute of Husbandry and Pharmaceutical Sciences, Chinese Academy of Agricultural \\ Sciences, Lanzhou, China
}

\section{Key Words}

IL-6 $\bullet$ Granulosa cells $\bullet$ IL-1 $\alpha \cdot$ MAPKs pathway $・ N F-k B$ pathway

\begin{abstract}
Background/Aims: IL-6 is one of the main cytokines in regulating ovarian follicular development and ovulation. However, the factors that regulate IL- 6 expression in follicles are still unclear. The aim of this study was to elucidate the mechanisms underlying the effect of IL-1 $\alpha$ on IL- 6 expression in granulosa cells. Methods: IL- 6 expression after IL-1 $\alpha$ with/ without inhibitors treatment was analyzed by RT-qPCR and ELISA. The phosphorylation of proteins induced by IL-1 $\alpha$ was analyzed by western blot. The intracellular cAMP level was assayed by immunoassay kit. Results: IL- $1 \alpha$ has a dose-dependent effect on IL- 6 expression in granulosa cells. This promoting effect can be significantly attenuated by Erk, c-Jun, p38 and IKB proteins inhibitors, respectively. Moreover, the phosphorylation levels of Erk, c-Jun, p38 and IKB $\alpha$ proteins were significantly increased after IL-1 $\alpha$ treatment. In addition, we also found that IL-1 $\alpha$ not only reversed the CAMP attenuated IL- 6 expression, but also increased IL- $1 \alpha$ mRNA expression in granulosa cells. Conclusion: The regulation of IL-1 $\alpha$ on IL- 6 expression is mediated by activation of MAPKs and NF-KB signaling pathways. Moreover, IL- $1 \alpha$ may regulate the ovulation-related genes expression in granulosa cells by an autocrine and/or paracrine manner.

(C) 2017 The Author(s)

Published by S. Karger AG, Basel
\end{abstract}

\section{Introduction}

Female fertility depends on the normal development and growth of ovarian follicles and eventually leads to ovulation. These processes are precisely regulated by many genes, including follicle stimulating hormone, luteinizing hormone and follicle derived steroid hormones [1, 2]. In addition, many local factors, including inflammatory cytokines play 
an important regulatory role in the ovarian cycle, especially in ovulation [3-5]. Moreover, it is also involved in the occurrence and development of ovulatory disorder infertility [68]. Inflammatory cytokines not only play a biological effect by themselves, but also have a complex regulatory relationship between each other, both at the gene level and the protein level.

IL-6 is produced by various types of cell, such as leukocytes, keratinocytes, endothelial cells, fibroblasts, and some tumor cells. It often displays hormone-like characteristics that affect homeostatic processes in many systems, including the reproductive system $[3,9,10]$. Similar to the effects in the inflammatory response, IL-6 also plays a dual role in regulation of follicular development and ovulation. It not only suppresses steroidogenesis induced by FSH $[11,12]$, but also promotes the LH receptor expression [13] and cumulus-oocyte complexes expansion [14]. Although previous studies have confirmed that IL-6 and its receptors expressed in granulosa cells [15-17], the factors that regulate IL-6 expression in ovarian follicles are still unknown.

IL-1 is another important type of inflammatory cytokines, mainly from the activated monocytes/macrophages and epithelial and endothelial cells. It induced expression of pro-inflammatory cytokines and chemokines through activating mitogen-activated protein kinase (MAPKs) and nuclear factor-kappa B (NF- $\mathrm{KB}$ ) signaling pathways by binding to IL-1 receptor type 1 (IL-1R1) on the cell membrane[18-20]. IL-1 is also one of the most important cytokines in local ovarian follicles [21]. It involved in several ovulation associated events such as synthesis of proteases, regulation nitric oxide and prostaglandin production [22]. On the other hand, previous studies has also found that hCG-induced ovulation rates were decreased in rats after treatment with IL-1 receptor antagonist (IL-1Ra) [23,24].Although IL- $1 \alpha$ and IL-1 $\beta$ are encoded by different genes, they exert similar biological effects by binding to the same receptor (IL-1R1). However, IL-1 $\alpha$ is more able to rapidly initiate the inflammatory cytokine expression both in the mature and precursor forms when binding to IL-1R1, and cause the aseptic inflammation, which has many similarities with ovulation [25]. It remains unclear whether IL- $1 \alpha$ can modulate the expression of IL- 6 in granulosa cells.

In this study, we examined the effects of IL- $1 \alpha$ on IL- 6 mRNA expression and protein production in granulosa cells. Moreover, the mechanisms of its action were also studied. The results showed that IL- $1 \alpha$ could up-regulates the IL- 6 expression via MAPKs and NF$\kappa \mathrm{B}$ signaling pathways. The regulatory effects of IL-1 $\alpha$ on ovarian granulosa cells may be achieved through an autocrine and/or paracrine manner.

\section{Materials and Methods}

\section{Antibodies and reagents}

Recombinant bovine IL-1 $\alpha$ was purchased from Kingfisher Biotech. U0126, SP600125, SB203580 and BAY11-7082 were obtained from Beyotime Biotechnology. Erk antibody, p-Erk antibody, c-Jun antibody,

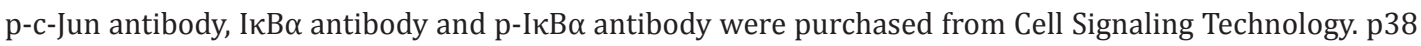
antibody, p-p38 antibody and $\beta$-actin antibody were purchased from LifeSpan BioSciences. Forskolin were purchased from Abcam.

\section{Granulosa cell cultures}

Bovine ovaries were collected from a local abattoir and brought to the laboratory in saline at $30-35^{\circ} \mathrm{C}$ within $2 \mathrm{~h}$ after euthanasia. Healthy follicles greater than $8 \mathrm{~mm}$ in diameter were separated after washed with sterile PBS three times. Ovarian follicles were cut in half, and then the follicle walls were washed with serum-free cell culture medium. Granulosa cells were collected by briefly centrifuge and washed three times with the culture medium. The cells were counted and assessed for viability using trypan blue staining. Granulosa cells were cultured in Dulbecco's Modified Eagle Medium/Nutrient Mixture F-12 (DMEM/ F12;Gibco,USA) supplemented with 1g/L bovine serum albumin (BSA;Sigma,USA), 1\% nonessential amino 


\section{Cellular Physiology Cell Physiol Biochem 2017;41:265-273 \begin{tabular}{l|l|l} 
and Biochemistry & $\begin{array}{l}\text { DOI: 10.1159/000456091 } \\
\text { Published onIIne: January 30, } 2017\end{array}$ & $\begin{array}{l}\text { C) } 2017 \text { The Author(s). Published by S. Karger AG, Basel } \\
\text { www.karger.com/cpb }\end{array}$
\end{tabular}}

Yang et al.: IL-1 $\alpha$ Up-Regulates IL-6 Expression in Granulosa Cells

acids(Gibco,USA), 1\% insulin-transferrin-selenium (ITS; Gibco,USA) in a humidified atmosphere under 5\% $\mathrm{CO}_{2}$ at $37^{\circ} \mathrm{C}$.

\section{Quantitative real-time PCR}

The granulosa cells were cultured in 6-well plates containing $1 \times 10^{6}$ viable cells in $2 \mathrm{ml}$ cell culture medium. The fresh medium was replaced $24 \mathrm{~h}$ before inhibitors and IL- $1 \alpha$ treatment. Total RNA was extracted from granulosa cells using Trizol reagent (Invitrogen, USA) according to the manufacturer's instructions. cDNA was generated from $1 \mu \mathrm{g}$ of total RNA by using the PrimeScript RT reagent kit (Takara, China). Realtime PCR was performed in a total volume of $25 \mu$ l containing $12.5 \mu$ l SYBR premix Ex Taq II, $1 \mu l$ forward primer $(10 \mu \mathrm{M}), 1 \mu \mathrm{l}$ reverse primer $(10 \mu \mathrm{M})$. The primers involved in the experiment were synthesized by Beijing Genomics Institute. The sequences of all primers used in this work are as follows: IL-6(forward, $5^{\prime}$ ATGCTTCCAATCTGGGTTCAATC- $3^{\prime}$; reverse, $5^{\prime}$-ACTCGTTCTGGAGGTAGTCCAGGTA- $3^{\prime}$ ), IL-1 $\alpha$ (forward, $5^{\prime}$ CCTCTCTCTCAATCAGAAGTCC-3'; reverse, $5^{\prime}$-CCACCATCACCACATTCTCC-3'), GAPDH(forward , $5^{\prime}$ GATGGTGAAGGTCGGAGTGAAC- 3 '; reverse, $5^{\prime}$-GTCATTGATGGCGACGATGT- 3 '). Relative quantifications of mRNA were performed using the $2^{-\triangle \Delta C \mathrm{~T}}$ comparative method. RNase free $\mathrm{dH}_{2} \mathrm{O}$ was used as the negative control reaction.

Measurement of IL-6 secretion by granulosa cells

Granulosa cells were cultured in 24 -well plates containing $1 \times 10^{5}$ viable cells in $1 \mathrm{ml}$ cell culture medium. The supernatant was collected and centrifuged at $24 \mathrm{~h}$ after the IL- $1 \alpha$ with or without inhibitors treatment. These samples were stored at $-80^{\circ} \mathrm{C}$ until assayed. IL- 6 secreted by granulosa cells was measured by ELISA kit (Abcam, UK). Absorbance was measured at $450 \mathrm{~nm}$ using a microplate reader. The concentration of IL-6 in the samples was calculated by comparison with the standard curve.

SDS/PAGE and western blot analyses

Granulosa cells were cultured in $60-\mathrm{mm}$ dishes and incubated with IL-1 $\alpha$ when the cells reached subconfluence. The cells were washed with pre-cooled PBS and then lysed with RIPA lysis buffer. The protein concentrations were determined by the BCA protein assay after the cell lysate centrifugation. The lysate $(20 \mu \mathrm{g})$ was then resolved on $12 \%$ SDS/PAGE gels and electrophoretically transferred to a polyvinylidene difluoride (PVDF) membrane. After blocking, the primary antibody was incubated with the protein antigen transferred to the PVDF membrane. After sufficient binding, secondary antibodies were combined with corresponding primary antibody. The immune complexes were visualized by the enhanced chemiluminescence reaction.

\section{Detection of intracellular Cyclic AMP levels}

Granulosa cells were treated with different concentrations of IL-1 $\alpha$ when the cells reached subconfluence. Competitive immunoassay kit (Abcam, UK) was used to determine of intracellular Cyclic AMP (cAMP) level in cells. Briefly, removed the media from adherent cells and add enough $0.1 \mathrm{M} \mathrm{HCl}$ to cover the bottom of the plate. The cells were incubated in $0.1 \mathrm{M} \mathrm{HCl}$ for $10 \mathrm{~min}$ at room temperature. Cell debris was removed by centrifugation after cells were uniform lysed. The supernatant were stored at $-80^{\circ} \mathrm{C}$ until assayed. Absorbance was measured at $405 \mathrm{~nm}$ using a microplate reader. The intracellular cAMP level in the samples was calculated by comparison with the standard curve.

\section{Data analysis}

All data shown are means \pm SEM from three independent experiments. Comparisons between groups were performed by one-way ANOVA. The significant differences between the control group and each treated group were determined using the Tukey test. A value of $\mathrm{P}<.05$ was considered significant.

\section{Results}

IL-1 $\alpha$ promotes IL-6 expression in granulosa cells

To investigate the effect of IL- $1 \alpha$ on IL- 6 biosynthesis, we analyzed the mRNA expression and protein production of IL- 6 in granulosa cells. Granulosa cells derived from large follicles 
were cultured in 6-well plates and treated with different concentrations of IL-1 $\alpha$ (0-10ng/ $\mathrm{ml}$ ). As shown in Fig. 1 A, IL-1 $\alpha$ has a dose-dependent effect on IL-6 mRNA expression. The expression levels of IL-6 mRNA were significantly increased after treatment with higher concentrations of IL- $1 \alpha(3 \mathrm{ng} / \mathrm{ml}$ and $10 \mathrm{ng} / \mathrm{ml})$ compared with lower concentration $(0-1 \mathrm{ng} /$ $\mathrm{ml}$ ). The change trend of IL-6 protein production in culture supernatant was consistent with mRNA expression in granulosa cells after IL-1 $\alpha$ treatment (Fig. 1 C).

\section{IL-1 $\alpha$ induced IL-6 expression is attenuated by inhibitors of MAPKs and NF- $\kappa B$ signaling pathways}

It is known that the IL-1 can induce synthesis and secretion of inflammatory cytokines through MAPKs and NF- $\kappa B$ signaling pathways [16]. However, little is known about the biological function of IL-1 $\alpha$ in local follicles. To identify the signaling pathways involved in IL-1 $\alpha$ up-regulation of IL- 6 expression in granulosa cells, we analyzed IL- 6 expression in the absence or presence of U0126, SP600125, SB203580 or BAY11-7082. As shown in Fig. $1 \mathrm{~B}$ and Fig. $1 \mathrm{D}$, the promoting effect of IL-1 $\alpha$ on the expression of IL-6, both at the gene level and protein level in granulosa cells was significantly attenuated by the corresponding inhibitor of MAPKs and NF- $\kappa B$ signaling pathway compared with the control group (IL-1 $\alpha$ at $10 \mathrm{ng} / \mathrm{ml}$ ).

\section{IL-1 $\alpha$ induces phosphorylation of Erk, c-Jun, $p 38$ and I $\kappa$ B $\alpha$ proteins}

To further verified the role of MAPKs and NF- $\kappa B$ signaling pathways in IL- $1 \alpha$ upregulation of IL-6 expression in granulosa cells, we used western blot analysis the protein

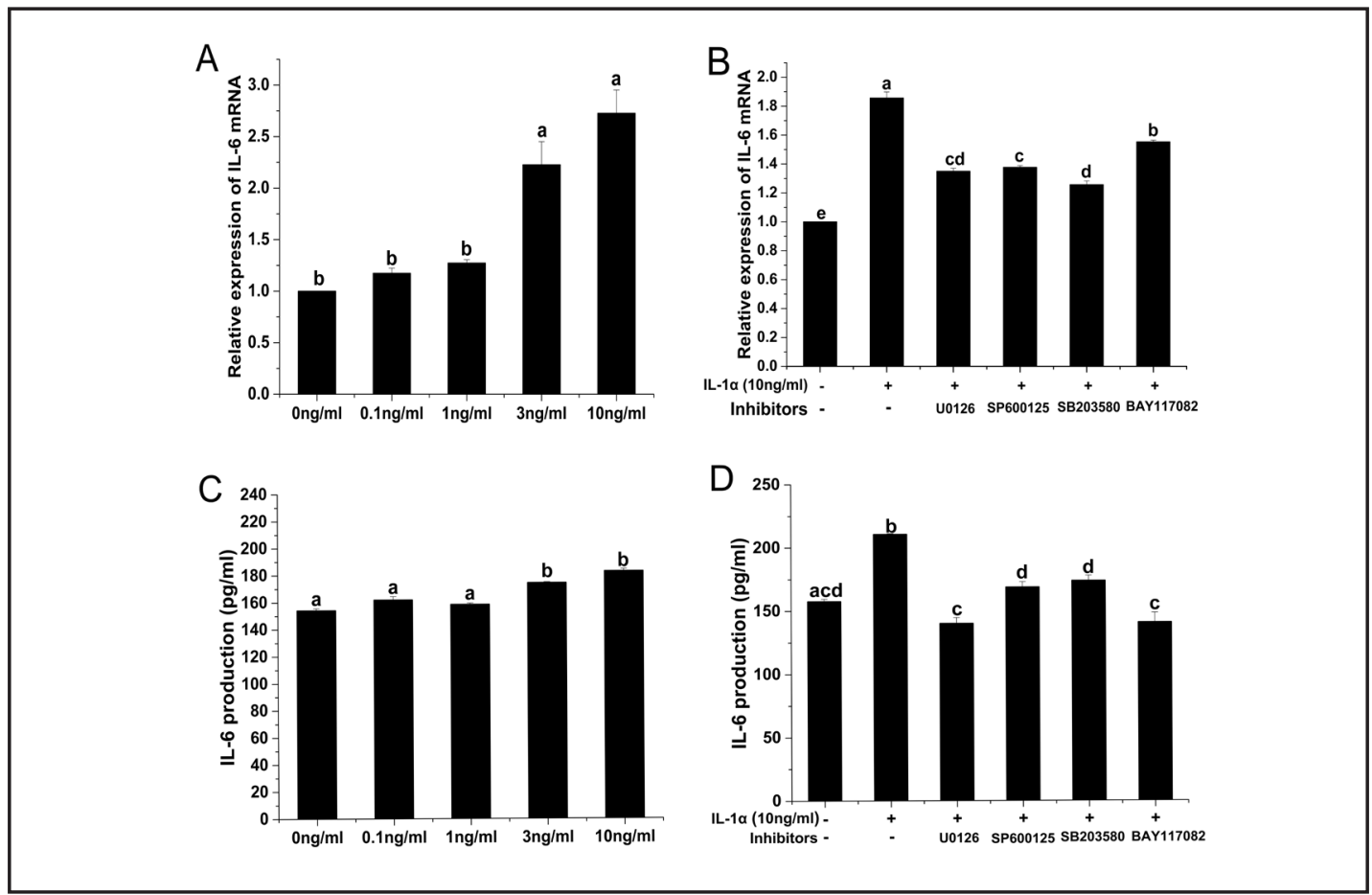

Fig. 1. Effects of IL-1 $\alpha$ on IL-6 expression in granulosa cells. A and C, Granulosa cells were treated with different concentrations of IL- $1 \alpha(0-10 \mathrm{ng} / \mathrm{ml})$, and the mRNA expression levels and protein production levels of IL- 6 were analyzed at $3 \mathrm{~h}$ or $24 \mathrm{~h}$ using RT-qPCR or ELISA, respectively. B and D, Granulosa cells were pretreated with Erk inhibitor U0126 $(10 \mu \mathrm{M})$, c-Jun inhibitor SP600125 (10 $\mu \mathrm{M})$, P38 inhibitor SB203580 $(10 \mu \mathrm{M})$ or IкB $\alpha$ inhibitor BAY11-7082 $(10 \mu \mathrm{M})$ for $1 \mathrm{~h}$. Cells were then treated with IL-1 $\alpha(10 \mathrm{ng} / \mathrm{ml})$ for $3 \mathrm{~h}$ or 24h. IL-6 mRNA and protein production levels were measured by RT-qPCR or ELISA, respectively. Results were expressed as the mean \pm SEM of at least 3 independent experiments. Values without a common letter were significantly different $(\mathrm{P}<.05)$.

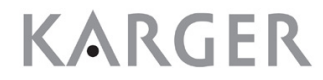




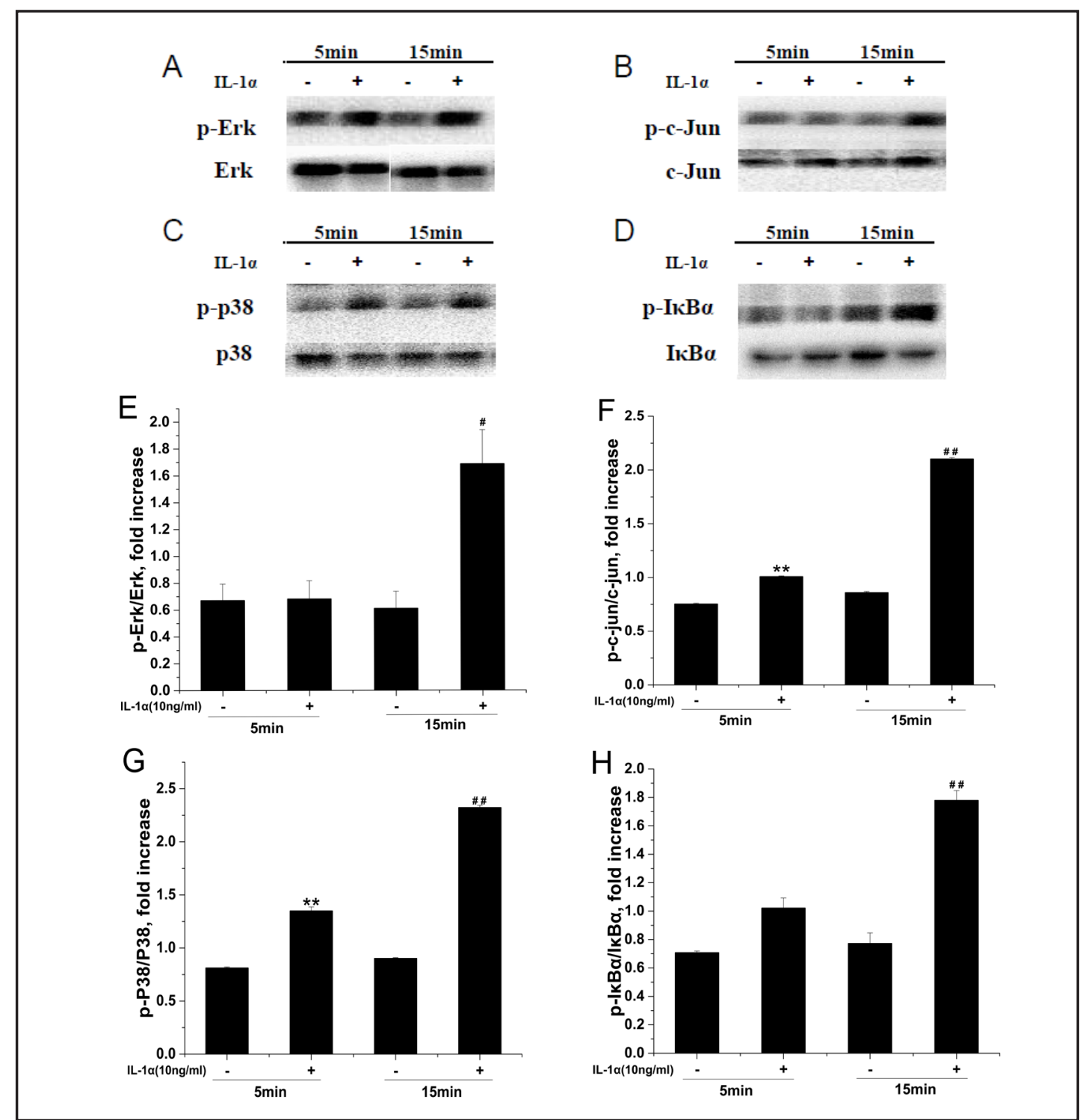

Fig. 2. Effects of IL- $1 \alpha$ on phosphorylation of Erk, c-Jun, p38 and IкB $\alpha$ proteins in granulose cells. A, B, C and D, The subconfluent granulose cells were exposed to IL-1 $\alpha(10 \mathrm{ng} / \mathrm{ml})$ for 5 or $15 \mathrm{~min}$. Whole-cell lysates were used for Western blot to detect levels of phosphorylated Erk (p-Erk),phosphorylated c-Jun(p-c-Jun),-

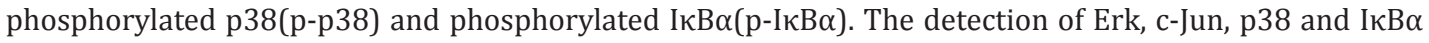
proteins served as a loading control. The phosphorylation level of the protein is expressed as the ratio of the phosphorylated protein to the total protein. Results were expressed as the mean \pm SEM of at least 3 independent experiments. $*(\mathrm{P}<.05)$ versus control group $(5 \mathrm{~min})$.\# $(\mathrm{P}<.05)$ versus control group $(15 \mathrm{~min})$.

phosphorylation induced by IL-1 $\alpha(10 \mathrm{ng} / \mathrm{ml})$ at $5 \mathrm{~min}$ and $15 \mathrm{~min}$. The results showed that the phosphorylation level of Erk after IL- $1 \alpha$ treatment was significantly higher than the control group at $15 \mathrm{~min}$ (Fig. $2 \mathrm{~A}$ and Fig. $2 \mathrm{E}$ ). We also found that the phosphorylation levels of c-Jun and p38 were significantly increased after exposure of IL- $1 \alpha$, either at $5 \mathrm{~min}$ or $15 \mathrm{~min}$ (Fig. 2 $\mathrm{B}, \mathrm{C}, \mathrm{F}$ and $\mathrm{G}$ ). In addition, the I $\kappa \mathrm{B} \alpha$ phosphorylation was significant increased at $15 \mathrm{~min}$ after IL- $1 \alpha$ treatment compared with the control group (Fig. 2 D and Fig. 2 H).

cAMP attenuated IL-6 expression is reversed by high concentration of IL-1 $\alpha$

It is known that cAMP is involved in the regulation of many cell functions, for example, regulation of cytokine synthesis and secretion [26-28]. Here, we examined the intracellular 

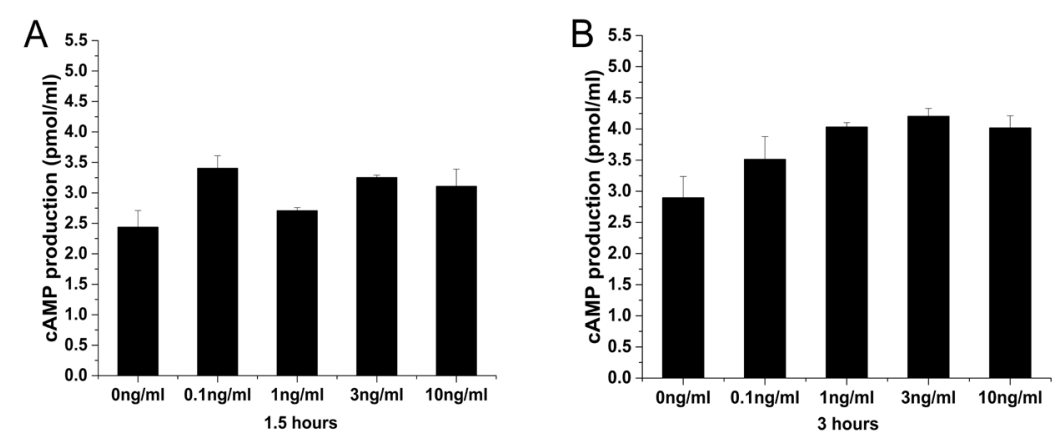

Fig. 3. Effects of IL-1 $\alpha$ on intracellular cAMP production in granulosa cells. Granulosa cells were treated with different concentrations of IL-1 $\alpha(0-10 \mathrm{ng} / \mathrm{ml})$, and the concentrations of intracellular cAMP were measured by ELISA at $1.5 \mathrm{~h}(\mathrm{~A})$ and $3 \mathrm{~h}(\mathrm{~B})$, respectively. Results were expressed as the mean $\pm \mathrm{SEM}$.

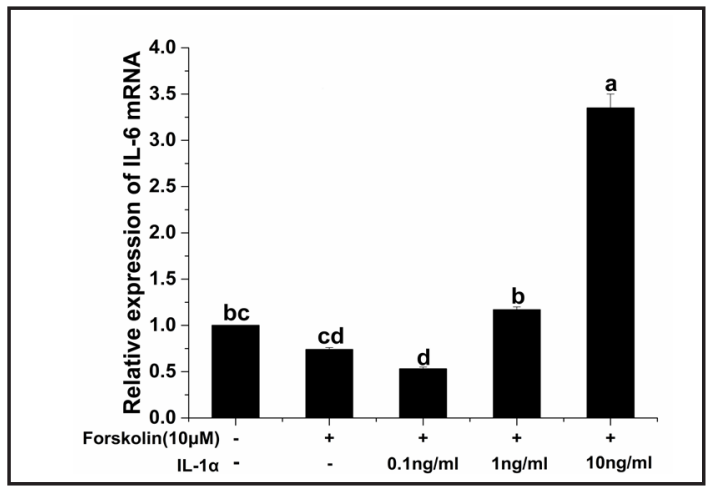

Fig. 4. Effects of cAMP on IL-6 mRNA expression in granulosa cells. Granulosa cells were pretreated with Forskolin $(10 \mu \mathrm{M})$, a cAMP specific agonist, for $1 \mathrm{~h}$. Cells were then treated with different concentrations of IL- $1 \alpha(0.1-10 \mathrm{ng} / \mathrm{ml})$ for $3 \mathrm{~h}$. IL- 6 mRNA levels were measured by RT-qPCR. Results were expressed as the mean \pm SEM of at least 3 independent experiments. Values without a common letter were significantly different $(\mathrm{P}<.05)$.

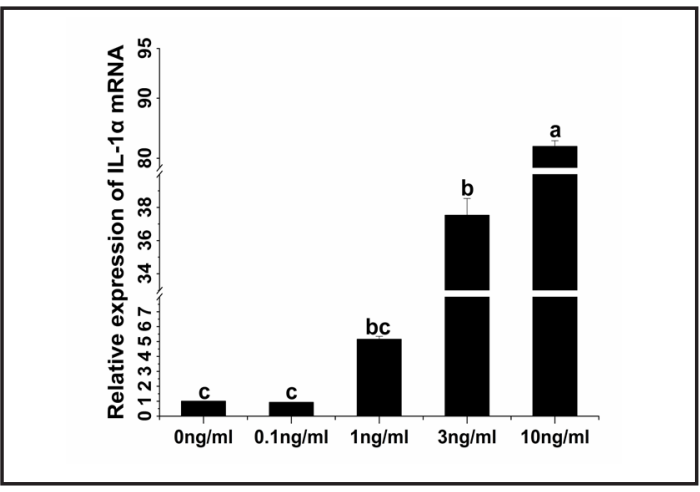

Fig. 5. Effects of IL- $1 \alpha$ on IL- $1 \alpha$ mRNA expression in granulosa cells. Granulosa cells were treated with different concentrations of IL- $1 \alpha(0-10 \mathrm{ng} / \mathrm{ml})$, and the mRNA levels of IL- $1 \alpha$ were analyzed at $3 \mathrm{~h}$ using RT-qPCR. Results were expressed as the mean \pm SEM of at least 3 independent experiments. Values without a common letter were significantly different $(\mathrm{P}<.05)$.

cAMP levels of granulosa cells after stimulated by different concentrations of IL-1 $\alpha$ (0-10ng/ $\mathrm{ml}$ ) for $1.5 \mathrm{~h}$ and 3h, respectively. As shown in Fig. $3 \mathrm{~A}$ and Fig. $3 \mathrm{~B}$, no significant differences were observed in intracellular cAMP levels between the treatment groups, neither at $1.5 \mathrm{~h}$ nor $3 \mathrm{~h}$. However, we still observed that the intracellular cAMP levels after IL- $1 \alpha$ treatment remained higher than the control group $(0 \mathrm{ng} / \mathrm{ml})$.

In order to further elucidate the effects of cAMP on IL-6 mRNA expression in granulosa cells, we analyzed IL- 6 expression after treatment with Forskolin $(10 \mu \mathrm{M})$ and different concentrations of IL-1 $\alpha(0.1,1$ and $10 \mathrm{ng} / \mathrm{ml})$. As shown in Fig. 4, expression level of IL-6 was reduced by Forskolin treatment alone, although no significant difference in statistics. Moreover, the expression level of IL-6 was significantly decreased after treatment with Forskolin and low concentration of IL- $1 \alpha(0.1 \mathrm{ng} / \mathrm{ml})$ compared with the control group. But, this attenuating effect can be reversed by high concentrations of IL- $1 \alpha(10 \mathrm{ng} / \mathrm{ml})$.

\section{$I L-1 \alpha$ promotes $I L-1 \alpha$ mRNA expression in granulosa cells}

Many studies have found that the level of IL-1 in follicular fluid and serum sharply increased at preovulatory period, and plays an important regulatory role in ovulationrelated gene expression [29-31]. Here, we used different concentrations of IL-1 $\alpha$ (0-10ng/ $\mathrm{ml}$ ) on the granulosa cells from large follicle with the characteristics of pre-ovulation 


\section{Cellular Physiology Cell Physiol Biochem 2017;41:265-273

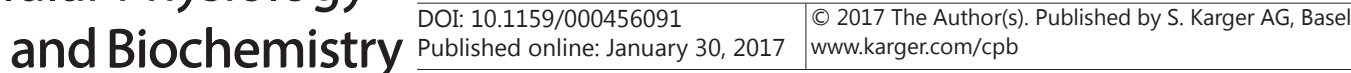 \\ Yang et al.: IL-1 $\alpha$ Up-Regulates IL-6 Expression in Granulosa Cells}

granulosa cells. The expression levels of IL- $1 \alpha$ mRNA were analyzed after treatment with IL-1 $\alpha$ h later. The results (Fig. 5) showed that IL-1 $\alpha$ has a dose-dependent effect on IL- $1 \alpha$ mRNA expression. Interestingly, a dramatic increased in IL-1 $\alpha$ mRNA expression level was observed after treatment with of IL-1 $\alpha$ at $10 \mathrm{ng} / \mathrm{ml}$.

\section{Discussion}

Inflammatory cytokines is the main cytokine type involved in the regulation of ovarian granulosa cell biological functions. In this study, we discovered that IL- $1 \alpha$ could up-regulate IL-6 expression in granulosa cells derived from large follicles. Moreover, our study further found that MAPKs and NF- $\kappa B$ signaling pathways involved in this regulation process.

Many studies have shown that cytokines, especially inflammatory cytokines involved in the regulation of follicular development and ovulation. Oocyte-cumulus complexes and granulosa cells were the main regulating objects of inflammatory cytokines [32]. Mutual induction of cytokine gene expression is an important feature of inflammatory cytokines. However, the factors that regulate the expression of IL-6 in the ovarian follicles are still unknown. In this study, we found that the expression levels of IL- 6 mRNA and protein in granulosa cells were up-regulated by high concentrations of IL- $1 \alpha$. It indicated that IL- $1 \alpha$ not only plays directly regulatory roles on the granulosa cells by itself, but also indirectly regulates the biological functions of cells through synthesis of other cytokines. In addition, we also found that IL-1 $\alpha$ could up-regulate the expression of IL- $1 \alpha$ mRNA in granulosa cells. Although IL-1 $\alpha$ can be expressed by granulosa cells, it may also be synthesized by other cells in the ovary. Especially in the preovulatory period, a large number of immune cells are rapidly recruited to the follicles and play a crucial role as facilitators of ovulation [33-35]. It suggests that IL- $1 \alpha$ may regulate the ovulation-related genes expression in granulosa cells by an autocrine and/or paracrine manner.

IL-1 induces cytokine gene expression mainly by triggering MAPKs and NF- $\kappa B$ signaling pathways. MAPKs signaling pathways involved in the regulation of diverse responses, including female follicular development and ovulation. However, the functions of cytokines will vary with different microenvironment. To clarify the mechanisms underlying the effect of IL- $1 \alpha$ on IL- 6 expression in granulosa cells, we specifically blocked the corresponding signaling pathways by using inhibitors. Our data show that up-regulation of IL-6 expression by IL- $1 \alpha$ was attenuated by inhibitors of U0126, SP600125, and SB203580 respectively. In order to further confirm the effect of MAPKs pathways on IL-6 expression after IL-1 $\alpha$ treatment, we detected phosphorylation of Erk, c-Jun and p38 proteins of MAPKs pathway by western blot. The results show that the phosphorylation of signaling proteins was significantly increased after IL- $1 \alpha$ treatment compared with the control group. The above studies indicated that the regulation of IL- $1 \alpha$ on IL- 6 expression is mediated by activation of MAPKs signaling pathway. NF- $\kappa B$ signaling pathway is another important pathway for IL-1 activation in the regulation of inflammatory cytokine gene expression. It not only plays the most important role in the immune system, but also regulates genes expression in many other systems. In this study, we found that IL- $1 \alpha$-induced IL- 6 expression in granulosa cells can be attenuated by NF- $\kappa$ B inhibitors (BAY11-7082). We also found that the phosphorylation

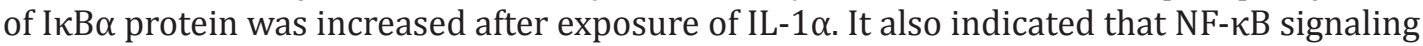
pathway is also involved in the IL- $1 \alpha$-induced IL- 6 expression in granulosa cells.

There is an interaction between cAMP and MAPKs signaling pathways in regulating gene expression [36]. It has been reported that cAMP can regulate the biosynthesis of IL-6 in many types of cells [37-39]. Here, we observed that the intracellular cAMP levels after IL-1 $\alpha$ treatment was higher than the control group, although no significant difference in statistics. In order to further clarify the regulatory role of cAMP in IL- $1 \alpha$-induced IL- 6 expression, Forskolin, a cAMP specific agonist, was used to treat cells in combination with IL- $1 \alpha$. The results showed that cAMP can reduce the IL- 6 mRNA expression, and this effect can be reversed by high concentrations of IL- $1 \alpha$. Inhibitory effect of cAMP on IL- 6 expression observed in the present study is consistent with previous study on lung fibroblasts [40]. It 
suggests that the cAMP may play a negative role in IL- $1 \alpha$-induced IL- 6 expression in ovarian granulosa cells. In addition, it is also imply that there is a regulatory relationship between IL-1 $\alpha$, IL- 6 and cAMP in processes of the follicular development and ovulation.

In summary, our study demonstrates that IL- $1 \alpha$ can promote IL- 6 expression in bovine granulosa cells. This effect is mediated through the MAPKs and NF- $\kappa B$ signaling pathways. IL- $1 \alpha$ may play a regulatory role in granulosa cells through an autocrine and/or paracrine manner.

\section{Acknowledgements}

This work was supported by the Dairy Industry Technology and Systems Projects (CARS-37), Agro-scientific Research in the Public Interest (201303040-01) and Chinese Central Government for Basic Scientific Research Operations in Commonweal Research Institutes (1610322014004).

\section{Disclosure Statement}

All authors declare that they have no conflict of interest.

\section{References}

-1 Richards JS, Russell DL, Ochsner S, Hsieh M, Doyle KH, Falender AE, Lo YK, Sharma SC: Novel signaling pathways that control ovarian follicular development, ovulation, and luteinization. Recent Prog Horm Res 2002;57:195-220.

- 2 Xu H,Deng K,Luo Q,Chen J,Zhang X,Wang X,Diao H,Zhang C:High Serum FSH is Associated with Brown Oocyte Formation and a Lower Pregnacy Rate in Human IVF Parctice. Cell Physiol Biochem 2016;39:677684.

3 Smolikova K, Mlynarcikova A, Scsukova S: Role of interleukins in the regulation of ovarian functions. Endocr Regul 2012;46:237-253.

-4 Field SL, Dasgupta T, Cummings M, Orsi NM: Cytokines in ovarian folliculogenesis, oocyte maturation and luteinisation. Mol Reprod Dev 2014;81:284-314.

-5 Liu H, Gao Y, Zhai B, Jiang H, Ding Y, Zhang L, Li C, Deng Q Yu X, Zhang J: The Effects of Polyadenylation Status on MPFs During In Vitro Porcine Oocyte Maturation. Cell Physiol Biochem 2016;39:1735-1745.

6 Amato G, Conte M, Mazziotti G, Lalli E, Vitolo G, Tucker AT, Bellastella A, Carella C, Izzo A: Serum and follicular fluid cytokines in polycystic ovary syndrome during stimulated cycles. Obstet Gynecol 2003;101:1177-1182.

7 Nash MA, Ferrandina G, Gordinier M, Loercher A, Freedman RS: The role of cytokines in both the normal and malignant ovary. Endocr Relat Cancer 1999;6:93-107.

8 Zolti M, Bider D, Seidman DS, Mashiach S, Ben-Rafael Z: Cytokine levels in follicular fluid of polycystic ovaries in patients treated with dexamethasone. Fertil Steril 1992;57:501-504.

-9 Hunter CA, Jones SA: IL-6 as a keystone cytokine in health and disease. Nat Immunol 2015;16:448-457.

10 Rincon M: Interleukin-6: from an inflammatory marker to a target for inflammatory diseases. Trends Immunol 2012;33:571-577.

11 Alpizar E, Spicer LJ: Effects of interleukin-6 on proliferation and follicle-stimulating hormone-induced estradiol production by bovine granulosa cells in vitro: dependence on size of follicle. Biol Reprod 1994;50:38-43.

12 Salmassi A, Lü S, Hedderich J, Oettinghaus C, Jonat W, Mettler L: Interaction of interleukin-6 on human granulosa cell steroid secretion. J Endocrinol 2001;170:471-478.

13 Imai F, Kishi H, Nakao K, Nishimura T, Minegishi T: IL-6 up-regulates the expression of rat LH receptors during granulosa cell differentiation. Endocrinology 2014;155:1436-1444.

-14 Liu Z, de Matos DG, Fan HY, Shimada M, Palmer S, Richards JS:Interleukin-6: an autocrine regulator of the mouse cumulus cell-oocyte complex expansion process. Endocrinology 2009;150:3360-3368. 


\section{Cellular Physiology Cell Physiol Biochem 2017;41:265-273

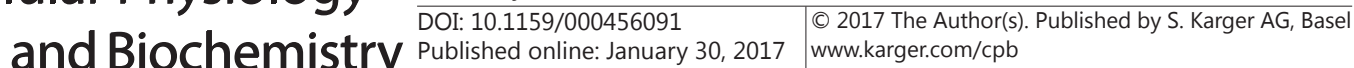

Yang et al.: IL-1 $\alpha$ Up-Regulates IL-6 Expression in Granulosa Cells

15 Machelon V, Emilie D, Lefevre A, Nome F, Durand-Gasselin I, Testart J: Interleukin-6 biosynthesis in human preovulatory follicles: some of its potential roles at ovulation. J Clin Endocrinol Metab 1994;79:633-642.

-16 Buyalos R P, Watson J M, Martinez-Maza 0: Detection of interleukin-6 in human follicular fluid. Fertil Steril 1992;57:1230-1234.

17 Gorospe WC, Hughes FM Jr, Spangelo BL: Interleukin-6: effects on and production by rat granulosa cells in vitro. Endocrinology 1992;130:1750-1752.

18 Sims JE, Smith DE: The IL-1 family: regulators of immunity. Nat Rev Immunol 2010;10:89-102.

19 Dinarello CA: Immunological and inflammatory functions of the interleukin-1 family. Annu Rev Immunol 2009;27:519-550.

20 Joosten L AB, Netea MG, Dinarello CA: Interleukin-1 $\beta$ in innate inflammation, autophagy and immunity. Semin Immunol 2013;25:416-424.

-21 Paulesu L, Jantra S, Ietta F, Brizzi R, Bigliardi E: Interleukin-1 in reproductive strategies. Evol Dev 2008;10:778-788.

22 Gérard N, Caillaud M, Martoriati A, Goudet G, Lalmanach AC: The interleukin-1 system and female reproduction. J Endocrinol 2004;180:203-212.

23 Simón C, Tsafriri A, Chun SY, Piquette GN, Dang W, Polan ML: Interleukin-1 receptor antagonist suppresses human chorionic gonadotropin-induced ovulation in the rat. Biol Reprod 1994;51:662-667.

24 Peterson CM, Hales HA, Hatasaka HH, Mitchell MD, Rittenhouse L, Jones KP: Interleukin-1 beta (IL-1 beta) modulates prostaglandin production and the natural IL-1 receptor antagonist inhibits ovulation in the optimally stimulated rat ovarian perfusion model. Endocrinol 1993;133:2301-2306. Uri-Belapolsky S, Shaish A, Eliyahu E, Grossman H, Levi M, Chuderland D, Ninio-Many L, Hasky N, Shashar D, Almog T, Kandel-Kfir M, Harats D, Shalgi R, Kamari Y: Interleukin-1 deficiency prolongs ovarian lifespan in mice. Proc Natl Acad Sci USA 2014;111:12492-12497.

-26 Hurme M: Modulation of interleukin-1 $\beta$ production by cyclic AMP in human monocytes. FEBS Lett 1990;263:35-37.

27 Platzer C, Meisel C, Vogt K, Platzer M, Volk HD: Up-regulation of monocytic IL-10 by tumor necrosis factor- $\alpha$ and cAMP elevating drugs. Int Immunol 1995;7:517-523.

-28 Novak T J, Rothenberg E V: cAMP inhibits induction of interleukin 2 but not of interleukin 4 in T cells. Proc Natl Acad Sci USA 1990;87:9353-9357.

29 Cannon JG, Dinarello CA: Increased plasma interleukin-1 activity in women after ovulation. Science 1985;227:1247-1249.

- 30 Simón C, Frances A, Piquette G, Polan ML: Immunohistochemical localization of the interleukin-1 system in the mouse ovary during follicular growth, ovulation, and luteinization. Biol Reprod 1994;50:449-457.

-31 Adashi EY: The potential role of interleukin-1 in the ovulatory process: an evolving hypothesis. Mol Cell Endocrinol 1998;140:77-81.

- 32 Richards JS, Liu Z, Shimada M: Immune-like mechanisms in ovulation. Trends Endocrinol Metab 2008;19:191-196.

33 Karaca T, Arikan S, Kalender H, Yoruk M: Distribution and heterogeneity of mast cells in female reproductive tract and ovary on different days of the oestrus cycle in Angora goats. Reprod Domest Anim 2008;43:451-456.

-34 Bukulmez O, Arici A: Leukocytes in ovarian function. Hum Reprod Update 2000;6:1-15.

-35 Smith MP, Flannery GR, Randle BJ, Jenkins JM, Holmes CH: Leukocyte origin and profile in follicular aspirates at oocyte retrieval. Hum Reprod 2005;20:3526-3531.

-36 Delidaki M, Gu M, Hein A, Vatish M, Grammatopoulos DK: Interplay of cAMP and MAPK pathways in hCG secretion and fusogenic gene expression in a trophoblast cell line. Mol Cell Endocrinol 2011;332:213-220.

- 37 Hershko DD, Robb BW, Luo G, Hasselgren PO: Multiple transcription factors regulating the IL-6 gene are activated by cAMP in cultured Caco-2 cells. Am J Physiol Regul Integr Comp Physiol 2002;283:1140-1148.

38 Zhang Y, Lin J X, Vilcek J: Synthesis of interleukin 6 (interferon-beta 2/B cell stimulatory factor 2) in human fibroblasts is triggered by an increase in intracellular cyclic AMP. J Biol Chem 1988;263:6177-6182.

-39 Robson RL, Westwick J, Brown Z: Interleukin-1-induced IL-8 and IL-6 gene expression and production in human mesangial cells is differentially regulated by cAMP. Kidney Int 1995;48:1767-1777.

40 Zitnik RJ, Zheng T, Elias JA: cAMP inhibition of interleukin-1-induced interleukin-6 production by human lung fibroblasts. Am J Physiol 1993;264:253-260. 